Abstracta Iranica Abstracta Iranica

Revue bibliographique pour le domaine irano-aryen

Volume 26 | 2005

Comptes rendus des publications de 2003

\title{
"Clothing in the Early Ghaznavid courts: hierarchy and mystification ». St. Ir., 32, 2 (2003), pp. 213-242.
}

\section{Rédaction}

\section{Q OpenEdition \\ 1 Journals}

Édition électronique

URL : http://journals.openedition.org/abstractairanica/2478

ISSN : 1961-960X

\section{Éditeur :}

CNRS (UMR 7528 Mondes iraniens et indiens), Éditions de l'IFRI

\section{Édition imprimée}

Date de publication : 15 mai 2005

ISSN : 0240-8910

\section{Référence électronique}

Rédaction, « «Clothing in the Early Ghaznavid courts: hierarchy and mystification ». St. Ir., 32, 2 (2003),

pp. 213-242. », Abstracta Iranica [En ligne], Volume 26 | 2005, document 273, mis en ligne le 07

décembre 2005, consulté le 25 septembre 2020. URL : http://journals.openedition.org/

abstractairanica/2478

Ce document a été généré automatiquement le 25 septembre 2020.

Tous droits réservés 


\section{"Clothing in the Early Ghaznavid courts: hierarchy and mystification ». St. Ir., 32, 2 (2003), pp. 213-242.}

\section{Rédaction}

INDEX

Thèmes : 5.0. Généralités

\section{AUTEURS}

\section{RÉDACTION}

Directeur de la revue et secrétariats (Paris et Téhéran) 